\title{
Chapter 8 \\ Implications for Regional Development Drawn from the Hometown Tax \\ Donation System-Aiming to Produce Regional Entrepreneurship
}

Hometown Tax Donation is a system where citizens donate to a region or regions they wish to endorse or support, and receive tax credit benefits in return. In effect, donors only pay 2000 yen out of their pockets. In addition, the system is a "bargain deal" since each municipality offers reciprocal gifts worth up to $30 \%$ of the donated amount, and donors essentially receive goods worth more than the 2000 yen they actually paid. On another note, donors can also choose not to receive gifts, in which case, the entire donation will be at the disposal of the municipality. In fact, when the Hometown Tax Donation system is used in civic crowdfunding-style, such as for disaster relief efforts or to resolve regional issues, gifts are often not offered or donors mostly decline gifts.

This system, which involves transfer of a portion of tax by residents' will, would be considered unacceptable in conventional theories of tax systems or local government finance, and is an irregular system to say the least. There are quite a few who oppose to the system itself, especially those specializing in the fields of tax systems and local government finance. Yet, there has never been a system that directed so much interest of urban residents toward rural areas, and in this respect, the Hometown Tax Donation system offers several insightful implications for considering regional development policies.

In Japan and many other advanced countries, there is no denying that issues of an aging society with declining birthrate, urbanization, and depopulation are imminent. Against this backdrop, we are faced with the challenge of contemplating how to manage each region, and ultimately, the entire country in a sustainable manner, and are still seeking solutions. To gain inspiration in this respect, this book verified the impact that Hometown Tax Donation and other systems have on regional revitalization and development from various aspects.

Chapter 2 outlined the need of municipalities to shift from conventional "administration"-oriented thinking to "management"-oriented thinking amid a situation where municipal revenue source must be secured independently rather than by depending on the central government. More specifically, it will become important to 
define non-locals as new customers of the region and establish marketing strategies targeting them. In other words, rural areas must obtain "foreign currency" by selling local products outside the region, and boost the circulation of people, goods and capital by increasing interacting populations.

Chapters 3 and 4 analyzed the impact that Hometown Tax Donation gifts has on local businesses. Analysis revealed that many of the gift providers were small enterprises who had not yet entered the e-commerce market. They not only lacked personnel and capital resource needed to execute online sales but did not have any know-how to begin with. Such businesses were offered the opportunity to deliver their products to non-local consumers owing to the emergence of the gift market, as well as support from municipalities in operations that come with normal online sales, such as order management, packaging and delivery, and customer (i.e., donor) support.

This implies that the gift market is serving as a dojo for fostering rural companies and SMEs, and suggests that creating demand in advance can instigate entrepreneurship by local businesses. Meanwhile, it is critical for regions and such businesses that a scenario be created where such businesses graduate from the dojo and strive competently in the regular e-commerce market, thereby actually earning "foreign currency." As long as the dojo remains to be a dojo, it will lead to mass production of businesses that rely indefinitely on the system of the Hometown Tax Donation gift market, which would be no different from conventional SME support measures that are dependent on subsidies, and therefore would not be sustainable. This aspect will be the next challenge. This book introduced cases where gift providers successfully exited the gift market, or used the gift market as a foothold for extending their business to the real e-commerce market. Each region needs to make a concerted effort to increase such cases.

To do so, support by regional financial institutions is also an important element, as described in Chap. 5. Ideally, regional financial institutions should not only extend loans but also serve a consulting role, and support local businesses together with chambers of industry and commerce and municipalities. As was revealed in analysis results, regional financial institutions are also aware of the positive impact that Hometown Tax Donation has on enhancing management capabilities of local businesses and revitalizing regions. However, financial institutions themselves have not yet reached the level of changing their lending activities. This may be because the size of each business is small or because both businesses and financial institutions are hesitant to make investments related to the gift market; however, taking a wait-and-see stance will cause opportunities to slip away amid the intensifying nation-wide competition to capture customers (i.e., donors) in the gift market. It is essential to foster an investment-oriented mindset in regional revitalization through industry-public-banking collaboration.

Chapter 6 explored the increase of associating and interacting populations. Survey results have revealed that those who make Hometown Tax Donations feel attached to the region, and as the next step, it is necessary to encourage such people to visit the region. The chapter introduced initiatives deployed by regions for increasing associating and interacting populations. Meanwhile, not a few municipalities have aimed to 
attract migrants or retain existing residents using funds procured through Hometown Tax Donation, and the MIC and media have described such cases as best practices; I therefore analyzed enhanced parenting support measures by Kamishihoro Town, Hokkaido Prefecture, financed by Hometown Tax Donations, as well as their impact, to validate the effectiveness of measures to attract migrants or promote settlement using Hometown Tax Donations.

While results cannot be generalized since demographics can be influenced by various factors, analysis results implied that enhanced parenting support measures may have an effect on attracting migrants from neighboring municipalities and retaining residents (i.e., suppressing population outflow). On the other hand, it was unclear whether such measures had sufficient impact on attracting migrants from distant areas, especially urban areas. This analysis provided two implications. Firstly, if rural municipalities become fixated on winning over residents, this could lead to a scramble for residents among neighboring municipalities, whereby, rural areas, already exhausted to begin with, would be embroiled in unproductive and exhausting competition among neighboring municipalities. On the other hand, the fact that such measures contribute to suppressing population outflow of the region should be deemed appealing for rural areas that face severe population outflow. Since halting population outflow is a significant challenge for rural municipalities, some municipalities would presumably be inclined to carry out measures for securing residents, represented by parenting support measures, even if this fuels competition with neighboring municipalities. There is no stopping such actions from the perspective of partial optimization.

However, what municipalities should actually strive to do is develop population policies targeting wider areas, such as promoting migrations from urban to rural areas, and small municipalities should avoid competing against each other over limited resource.

Chapter 7 referred to civic crowdfunding that uses Hometown Tax Donation to resolve regional and social issues. The fact that procuring funds through Hometown Tax Donation or crowdfunding enables resolving imminent issues that cannot be attended to otherwise under a silver democracy, will be significantly valuable in sustainable regional development. This will allow more flexibility in the process for securing budgets within local governments, and enable strategic investments that the region believes are necessary for its future. Achieving differentiation through gifts is no longer easy now that the value of gifts has been capped to $30 \%$ of donated amount according to 2019 law revisions; therefore, it is important to attract donors by effectively gaining their empathy for the story behind the regions' machizukuri.

In addition, soliciting donations by presenting their effective usage is consistent with the originally envisioned form of Hometown Tax Donation. Moving forward, an increase in the number of regional and social issues that are resolved through civic engagement by using civic crowdfunding, should lead to regional revitalization and development. This will ultimately help boost associating and interacting populations, and contribute to forging an economy where people, goods and capital circulate between urban and rural areas. 
It is imperative that policy makers leverage the above policy implications and that local businesses seize new businesses opportunities and extra-regional sales opportunities that they would not have been able to on their own. To achieve this end, it is necessary for rural areas to foster an entrepreneur mindset and make a full-fledged effort to create a culture where challenges, however small, are actively taken on.

One thing we should bear in mind, and which would be an area for future research, is that this system needs continuous improvement. 10 years have passed since this system was introduced in Japan, during which time there were several reforms. One major argument arising from this system is that it might be amplifying the budget imbalance among rural municipalities. Also, since the majority of people participating in Hometown Tax Donation reside in urban areas, those areas are losing tax revenues. We should avoid a situation where the system benefits only a handful of municipalities and increases inequality between urban and rural areas, as well as among rural municipalities. Long-term effects deriving from this system are yet to be examined carefully.

Open Access This chapter is licensed under the terms of the Creative Commons AttributionNonCommercial-NoDerivatives 4.0 International License (http://creativecommons.org/licenses/bync-nd/4.0/), which permits any noncommercial use, sharing, distribution and reproduction in any medium or format, as long as you give appropriate credit to the original author(s) and the source, provide a link to the Creative Commons license and indicate if you modified the licensed material. You do not have permission under this license to share adapted material derived from this chapter or parts of it.

The images or other third party material in this chapter are included in the chapter's Creative Commons license, unless indicated otherwise in a credit line to the material. If material is not included in the chapter's Creative Commons license and your intended use is not permitted by statutory regulation or exceeds the permitted use, you will need to obtain permission directly from the copyright holder.

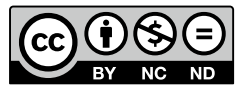

